\title{
Neuropsychiatric manifestation of confusional psychosis due to Cryptococcus neoformans var. grubii in an apparently immunocompetent host: a case report Peralam Yegneswaran Prakash* and Rao P Sugandhi
}

\author{
Address: Department of Microbiology, 2nd Floor, Centre for Basic Sciences Building, Kasturba Medical College, Manipal University, Madhav \\ Nagar, Manipal, Karnataka, 576104, India \\ Email: Peralam Yegneswaran Prakash* - prakashpayyanur@gmail.com; Rao P Sugandhi - psraos82@yahoo.co.in \\ * Corresponding author
}

Published: 25 November 2009

Cases Journal 2009, 2:9084 doi:10.1186/1757-1626-2-9084

This article is available from: http://www.casesjournal.com/content/2/I/9084

(c) 2009 Prakash and Sugandhi; licensee BioMed Central Ltd.

This is an Open Access article distributed under the terms of the Creative Commons Attribution License (http://creativecommons.org/licenses/by/2.0), which permits unrestricted use, distribution, and reproduction in any medium, provided the original work is properly cited.
Received: 13 October 2009

Accepted: 25 November 2009

\begin{abstract}
Cognitive disorders like dementia, delirium, depression, anxiety, psychosis and mania are the commonest neuropsychiatric manifestations. We discuss here a case of an adult women presenting with neuropsychiatric manifestations of confusional psychosis owing to Cryptococcosis. The principal cause was consequently established by culturing Cryptococcus neoformans from the cerebrospinal fluid confirmed as $C$. neoformans var. grubii (Serotype $A$ ) by genotypic methods. Antifungal therapy with IV Amphotericin $B$ lead to sustained improvement and recovery of the patient from behavioural disorders. The case discussed here invokes the need for the vigilance it demands in delineating organic brain syndromes for a favourable treatment outcome.
\end{abstract}

\section{Introduction}

Among the vast diversity of uncanny neuropsychiatric manifestations a minor section is attributed to agents of infectious diseases. The involvement of Cryptococcus neoformans as a causal agent in mounting behavioural disorders like psychosis is of rare occurrences [1]. Human Cryptococcosis often presents with diverse spectrum of manifestations ranging from pulmonary, central nervous system, cutaneous, osseous and occasionally with potential dissemination in immunocompromised hosts [2]. The central nervous system involvement leading to meningitis invariably ends in fatality if untreated. In the setting of a developing country the victims of psychiatric ailments are brought in for an expert medical intervention only as the symptoms aggravate. Thus the patient often suffer owing to the extend course of the disease. The Indolent progression of Cryptococcosis due to C. neoformans var. grubii in an apparently immunocompetent patient leading a protracted course of clinical manifestation as confusional psychosis is discussed in this report.

\section{Case Presentation}

A 28-year-adult woman hailing from a rural area in India was admitted to the psychiatric unit of our tertiary case hospital with complaints of abrupt and dwindling mental status in the preceding 3 months. She presented with noticeable behavioural changes characterized by brief episodes of confusion, hallucination, delusion and psychosis. Patient was unable to distinguish reality from fantasy. There was neither a family history psychiatric ailments nor a past history of diagnosed behavioural disorder in the patient. Upon examination, the muscle tone and brain CT scan and EEG were normal and she was not photophobic. A tentative mood disorder was diagnosed and patient was started on Olanzapine $5 \mathrm{mg} /$ day. 
But a gradual deterioration in the patient mental status occurred during the $4^{\text {th }}$ day of admission with periodic episodes of fever. At this time a lumbar puncture was performed with a recorded opening pressure of $120 \mathrm{~mm}$. The CSF was faintly turbid with a protein content of $1.25 \mathrm{~g} / \mathrm{l}$, sugar $1.8 \mathrm{mmol} / \mathrm{l}$ and $4-5 \mathrm{WBC} / \mathrm{ml}$. A portion of CSF sample send to perform microbiological investigations turned out to be negative for bacterial and viral agents including HIV tests. The CSF microscopy examination using India Ink preparation was negative for Cryptococcus. A CSF Culture for Cryptococcus was carried out which on prolonged incubation up to 1 week revealed a few colonies of Cryptococcus. Biochemical and physiological tests were performed as per standard mycological methods and the isolate presumptively identified as Cryptococcus neoformans. Subsequently the genotyping results confirmed the isolate being C. neoformans var. grubii.

A confirmed diagnosis of meningitis due to Cryptococcus neoformans was made and patient shifted to the General medicine unit. Treatment with IV Amphotericin B initiated and the psychotropic medicaments discontinued. The patient retained mental stability at the end of 12 weeks and was discharged from the hospital. Upon follow up after a year the patient remained well with no recurrence of psychosis.

\section{Discussion}

The initial presentation of behavioural disorder in our patient had made the patients caretakers and local therapists believe it to be linked with an event concerned with devilish possession. Subsequently the mycological diagnosis leading to adequate antifungal treatment could bring about complete resolution of psychotic symptoms.

Summary of the patient demographic features with the typical presenting signs and symptoms, definitive diagnostic test and outcome is tabulated in [Table 1].

Although there is no significant influence on the clinical outcome based on the varietal types of Cryptococcus neoformans, often C. neoformans var. gattii has been found to have involved in immunocompetent host [3]. On the other hand in the present case the agent involved was $C$. neoformans var grubii and is the first report from southern state of India.

It is interesting to note the lack of pathognomonic radiological features made the confirmed diagnosis a challenging endeavour. In addition psychosis and associated behavioural disorder is tempted to over look the true aetiology leading to misdiagnosis in the early stage. It is difficult to pinpoint how much of the resolution was due to

Table I: Reported cases of neuropsychiatric manifestations due to Cryptococcus neoformans

\begin{tabular}{|c|c|c|c|c|c|c|}
\hline Reference & Age, Gender & Location & Symptoms & Immune status & $\begin{array}{c}\text { Definitive } \\
\text { diagnostic test }\end{array}$ & $\begin{array}{l}\text { Treatment/ } \\
\text { Outcome }\end{array}$ \\
\hline Present case & 28, Female & India & $\begin{array}{l}\text { Insomnia, Irritability, } \\
\text { Psychosis, impaired } \\
\text { reality testing, } \\
\text { confusion }\end{array}$ & Immune-competent & CSF Culture & $\begin{array}{c}\text { Amphotericin B; } \\
\text { Recovery after } 12 \\
\text { weeks }\end{array}$ \\
\hline Ref. [3] & 25, Female & China & $\begin{array}{l}\text { Elated mood, } \\
\text { logorrhoea, flight of } \\
\text { ideas, disorientation, }\end{array}$ & Not mentioned & $\begin{array}{l}\text { CSF Culture, } \\
\text { Cryptococcal } \\
\text { antigen test }\end{array}$ & $\begin{array}{l}\text { Amphotericin B; } \\
\text { Recovery after } 16 \\
\text { weeks }\end{array}$ \\
\hline Ref. [4] & 63, Male & USA & $\begin{array}{l}\text { Insomnia, restless, } \\
\text { irritable, agitation, } \\
\text { social dis-inhibition }\end{array}$ & Not mentioned & $\begin{array}{l}\text { CSF Culture, } \\
\text { Cryptococcal } \\
\text { antigen test }\end{array}$ & $\begin{array}{c}\text { Amphotericin B; } \\
\text { Recovered }\end{array}$ \\
\hline Ref. [5] & 32, Male & USA & $\begin{array}{l}\text { Insomnia, auditory } \\
\text { and visual } \\
\text { hallucinations, } \\
\text { paranoid delusions }\end{array}$ & $\begin{array}{c}\text { Immune- } \\
\text { compromised }\end{array}$ & $\begin{array}{l}\text { CSF (India Ink) } \\
\text { Blood culture }\end{array}$ & Recovered \\
\hline Ref. [5] & 35, Male & USA & $\begin{array}{c}\text { Poor sleep, Intrusive, } \\
\text { hyperactive }\end{array}$ & $\begin{array}{c}\text { Immune- } \\
\text { compromised }\end{array}$ & CSF (India Ink) & Died \\
\hline Ref. [6] & 38, Male & Papua New Guinea & $\begin{array}{l}\text { Restlessness, elated } \\
\text { mood, delusions }\end{array}$ & Immune-competent & $\begin{array}{c}\text { Serum Cryptococcal } \\
\text { antigen test }\end{array}$ & Died \\
\hline Ref. [7] & 27, Male & France & $\begin{array}{l}\text { Hallucinations, } \\
\text { Delusional ideas }\end{array}$ & $\begin{array}{l}\text { Immune- } \\
\text { compromised }\end{array}$ & $\begin{array}{c}\text { CSF (India Ink) } \\
\text { Culture }\end{array}$ & Recovered \\
\hline Ref. [8] & 22, Male & Kuwait & Confusion Psychosis & Not mentioned & CSF Culture & $\begin{array}{c}\text { Amphotericin and 5- } \\
\text { flurocytosine; } \\
\text { Recovered }\end{array}$ \\
\hline Ref. [9] & 57, Male & Israel & Vascular dementia & Immune-competent & $\begin{array}{l}\text { CSF (India Ink) } \\
\text { Culture } \\
\text { Serum and CSF } \\
\text { Cryptococcal } \\
\text { antigen test }\end{array}$ & $\begin{array}{c}\text { Amphotericin B, 5- } \\
\text { Flucytosine followed } \\
\text { by Flucanazole; } \\
\text { Recovered }\end{array}$ \\
\hline
\end{tabular}


the prior antipsychotic drug since it was discontinued as soon as the mycological diagnosis of cryptococcosis was confirmed. The existing literature has very few information on the evidence for the number of cases in which Cryptococcus neoformans may be involved with psychotic manifestation. In this case where the antipsychotic treatment was discontinued and the patient was put on antifungal treatment for duration of 12 weeks there was complete cure and we implicate the pathogen role in the root cause for the psychoses.

In earlier literature describing neuropsychiatric manifestation of cryptococcosis the varietal confirmation of the Cryptococcus neoformans isolates has not been carried out [4-10]. In this present case we have attempted to provide this date by genotyping the isolate. This could be important as the variety types has different ecological, epidemiology and virulence properties and will help us to understand the diverse presentation of cryptococcosis in a wider population especially in a scenario where the immune status of the host is difficult to determine.

Too frequently a psychiatric diagnosis is given prematurely and often an aggressive thought of infections as a differential diagnosis is given less priority. The case discussed here invokes the need for the vigilance it demands in delineating organic brain syndromes in significantly reducing the mortality with complete recovery from the neuropsychiatric manifestations.

\section{Consent}

The patient deteriorated mental status made the informed consent procedure reasonably difficult. To this extent consent was obtained from the patient's next-of-kin and effort has been made so that patient identity remains anonymous and there is no reason to think that the patient or their family would object to publication.

\section{Competing interests}

The authors declare that they have no competing interests.

\section{Authors' contributions}

PYP followed up the case, did the literature review and drafted the manuscript. PSR analysed the case. Both authors read and approved the final manuscript.

\section{Acknowledgements}

We acknowledge Dr. Peter Williamson, University of Illinois, Chicago for Molecular typing and confirmation of the Cryptococcus neoformans isolate.

\section{References}

I. de Ibanez-Valdes LF, Foyaca-Sibat H, Mfenyana K, Chandia J, Gonzalez-Aguilera H: Neuropsychiatry Manifestations In Patients Presenting Cryptococcal Meningitis. The Internet Journal of Neurology 2005, 5(I): [http://www.ispub.com/journal/ the internet journal of neurology/volume 5 number $\quad$ 22/article/ neuropsychiatry manifestations in patients presenting cryptococca meningitis.html].

2. Mitchell TG, Perfect JR: Cryptococcosis in the era of AIDS-- 100 years after the discovery of Cryptococcus neoformans. Clin Microbiol Rev 1995, 8:515-548.

3. Mitchell DH, Sorrell TC, Allworth AM, Heath CH, McGregor AR, Papanaoum K, Richards MJ, Gottlieb T: Cryptococcal disease of the CNS in immunocompetent hosts: influence of cryptococcal variety on clinical manifestations and outcome. Clin Infect Dis 1995, 20:6II-6I6.

4. Tan WK, Ungvari GS, Leing CM: Cryptococcal meningitis mimicking primary mania in a young female. Gen Hosp Psychiatry 2005, 27:298-303.

5. Thienhaus OJ, Khosla N: Meningeal cryptococcosis misdiagnosed as a manic episode. Am J Psychiatry I984, I4 I: |459-| 460.

6. Johannessen DJ, Wilson LG: Mania with cryptococcal meningitis in two AIDS patients. J Clin Psychiatry 1988, 49:200-201.

7. Johnson FY, Naragi S: Manic episode secondary to cryptococcal meningitis in a previously healthy adult. $P N G$ Med J 1993, 36:59-62.

8. Goeb Jean-Louis, Leon Virginie, Kechid Geraldine: Cryptococcal Meningitis with Acute Psychotic Confusion in a Sarcoid Patient. Prim Care Companion J Clin Psychiatry 2007, 9:393-394.

9. Sa'adah MA, Araj GF, Diab SM, Nazzal M: Cryptococcal meningitis and confusional psychosis: a case report and literature review. Trop Geogr Med 1995, 47:224-226.

10. Aharon-Peretz J, Kliot D, Finkelstein R, Ben Hayun R, Yarnitsky D, Goldsher D: Cryptococcal meningitis mimicking vascular dementia. Neurology 2004, 62:2135.

\section{Publish with Bio Med Central and every scientist can read your work free of charge}

"BioMed Central will be the most significant development for disseminating the results of biomedical research in our lifetime. "

Sir Paul Nurse, Cancer Research UK

Your research papers will be:

- available free of charge to the entire biomedical community

- peer reviewed and published immediately upon acceptance

- cited in PubMed and archived on PubMed Central

- yours - you keep the copyright

Submit your manuscript here:

http://www.biomedcentral.com/info/publishing_adv.asp 